\title{
TEKNOLOGI PEMANTAUAN KUALITAS AIR ONLINE BERBASIS GSM DENGAN METODE SMS DI SUNGAI KAPUAS
}

\author{
Heru Dwi Wahjono \\ Pusat Teknologi Lingkungan, BPPT \\ Jl. M.H. Thamrin No. 8 Gd. II Lt. 18 Jakarta 10340
}

\begin{abstract}
Kapuas River is the largest river on the Borneo island and become the source of water for the people of this island. In Pontianak City, Kapuas River is become the source of raw water for the local water company (PDAM). To maintain product quality, PDAM Pontianak always monitor this river water quality. During the dry season or during high water, raw water quality Kapuas river becomes salty. Meanwhile, during the rainy season brings torrential river water from upstream mud and water turned into peat. To monitor water quality changes in the Kapuas river in the intake location, PDAM Pontianak has installed an online and real time water quality monitoring system using GSM technology. This paper discusses the installation process online water quality monitoring system starting from the preparation, determination of the location until the process of testing the system. The results of monitoring by the monitoring system is expected to assist the production department to determine the necessary action if there is a change of quality of raw water Kapuas river.
\end{abstract}

Keywords: GSM Communication Based Online Monitoring System, Telemetry System, Intake PDAM Pontianak, Multi Probe Digital Sensor, Water Treatment Plant

\section{PENDAHULUAN}

\subsection{Latar Belakang}

Kota Pontianak adalah ibu kota Provinsi Kalimantan Barat yang terkenal sebagai Kota Khatulistiwa karena dilalui garis lintang nol derajat bumi. Di bagian utara kota ini, yaitu daerah Siantan, terdapat monumen atau Tugu Khatulistiwa yang dibangun pada tempat yang tepat dilalui garis lintang nol derajat bumi. Kota ini juga dilalui Sungai Kapuas yang merupakan sungai terpanjang di Indonesia. Sungai Kapuas menjadi menjadi sumber air untuk kebutuhan air bersih di kota ini, sehingga sudah menjadi urat nadi kehidupan di kota ini (1).

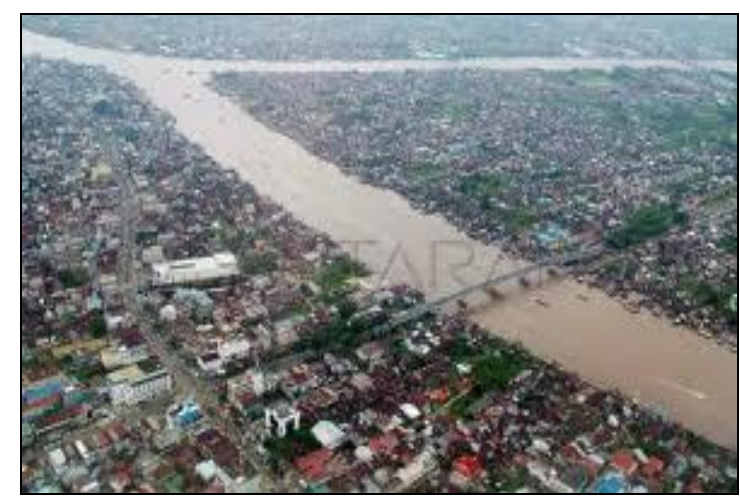

Gambar 1. Foto Udara Sungai Kapuas

Dengan tingkat pertumbuhan penduduk sekitar 2,14\% per tahun, Kota Pontianak saat ini memiliki jumlah penduduk kurang lebih 543.996 jiwa (2). Seiring dengan meningkatnya jumlah penduduk, kebutuhan akan penyediaan air bersih juga semakin meningkat. Pemakaian air Sungai Kapuas sebagai sumber air baku bagi kebutuhan hidup sehari-hari juga semakin meningkat. Melalui PDAM Pontianak kebutuhan air bersih seluruh warga kota ini telah dapat dilayani (3).

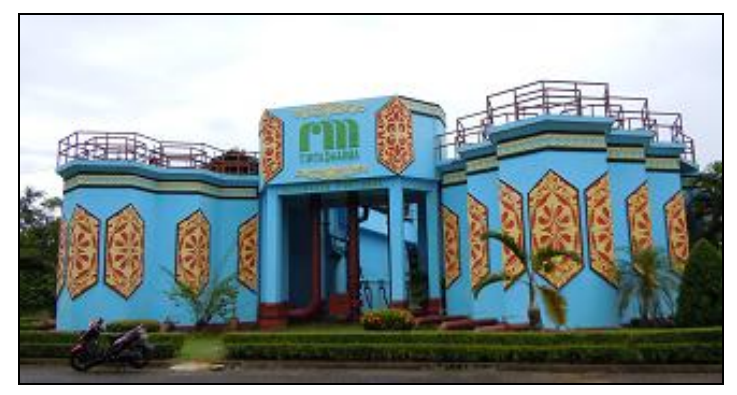

Gambar 2. Sarana IPA di PDAM Pontianak

Dari hasil survei yang dilakukan oleh PDAM, perkembangan jumlah pelanggan air minum PDAM meningkat dari tahun ke tahun, diiringi dengan peningkatan jumlah air yang disalurkan. Pada tahun 2003 jumlah pelanggan dari semua jenis pelanggan telah mengalami peningkatan. Untuk penyaluran air ke pelanggan, yang terbesar adalah ke rumah tempat tinggal $\left(12.469 .515 \mathrm{~m}^{3}\right)$ dan yang terkecil adalah jenis pelanggan lain-lain $\left(56.287 \mathrm{~m}^{3}\right)$ dengan total air yang disalurkan adalah sebanyak $16.287 .563 \mathrm{~m}^{3}$. Sedangkan cakupan pelayanan PDAM Pontianak baru mencapai $72 \%$ dari yang ditargetkan $100 \%$ 
pada tahun 2010-2011 dengan produksi air bersih terdistribusi sebanyak \pm 1.019 liter/detik dari kapasitas terpasang 1.210 liter/detik (4).

Menurunnya kualitas air Sungai Kapuas saat ini mendorong manajemen PDAM Pontianak untuk meningkatkan kualitas produksi dengan melakukan pemantauan secara rutin sumber air bakunya. Penurunan kualitas air baku pada intake PDAM Pontianak yang berada di jalan Imam Bonjol ini disebabkan oleh intrusi air laut yang terjadi ke arah daratan. Pada saat musim kemarau atau saat air pasang, kualitas air baku sungai Kapuas ini menjadi asin. Sedangkan pada saat musim hujan lebat air sungai ini membawa lumpur dari hulu dan berubah menjadi air gambut. Dari hasil pemantauan kualitas yang telah dilakukan, diperoleh kualitas kadar garam air bakunya sebesar 2000 ppm sedangkan baku mutu yang diperbolehkan adalah 800 ppm (5).

Perubahan kualitas air baku pada intake di Sungai Kapuas ini perlu diantisipasi oleh bagian produksi PDAM untuk melakukan proses pengolahan air yang berbeda sesuai dengan kualitas air baku yang akan diolah. Untuk itu perlu dilakukan pengamatan secara kontinyu perubahan kualitas air sungai di lokasi intake PDAM. Kegiatan pemantauannya saat ini telah dilakukan secara manual, yaitu dengan analisa kualitas air bakunya melalui laboratorium yang ada. Namun proses pengamatan secara manual dirasa kurang memadai, sehingga diperlukan teknologi pemantauan secara online dan realtime kualitas air yang dapat memberikan informasi secara langsung kepada operator agar dapat segera diambil tindakan jika diperlukan. Untuk itu pada tahun 2010, PDAM Pontianak dengan dana bantuan program CSR (Corporate Social Responsibility dari PT. Nokia Siemens Network telah memasang sistem pemantuan kualitas air online menggunakan teknologi GSM di lokasi intake air baku Instalasi Pengolahan Air (IPA) yang berada di tepi Sungai Kapuas ${ }^{(6)}$.

\subsection{Tujuan Dan Sasaran}

Tujuan dari kegiatan adalah melakukan instalasi sistem pemantauan kualitas air secara online dan realtime menggunakan teknologi komunikasi GSM di lokasi intake di tepi Sungai Kapuas dalam rangka pengamatan kualitas sumber air baku PDAM Pontianak. Sedangkan sasaran dari kegiatan ini adalah terpasangnya sistem pengamatan kualitas air yang dapat membantu divisi produksi PDAM Pontianak dalam mengantisipasi perubahan kualitas air Sungai Kapuas yang terjadi akibat pengaruh intrusi air laut.

\subsection{Metodologi}

Metodologi yang digunakan untuk melaksanakan kegiatan instalasi sistem monitoring kualitas air online ini adalah adalah sebagai berikut :

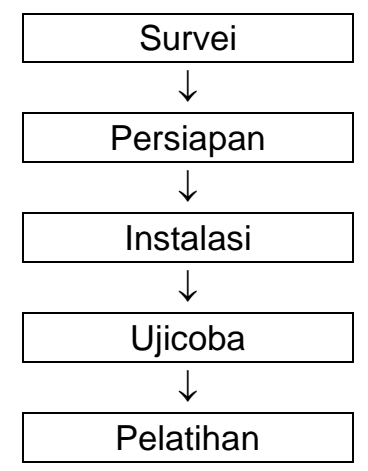

Gambar 3. Metodologi Instalasi Sistem

a. Survei lokasi, dilakukan dengan mengamati lokasi tempat pemasangan peralatan sistem online monitoring. Data yang diperlukan adalah lokasi penempatan sensor dan data logger serta teknis pengamanan peralatan di lapangan.

b. Persiapan peralatan, dilakukan dengan mempersiapkan peralatan monitoring, yaitu kalibrasi sensor $\mathrm{DO}$ dan $\mathrm{pH}$ dengan larutan standar, pengecekan rangkaian data logger serta pengisian pulsa pada GSM modem.

c. Instalasi/pemasangan peralatan, dilakukan pada titik lokasi yang telah ditentukan dan dinilai aman untuk menempatkan sensor dan data logger. Sensor harus selalu tercelup ke dalam air sedangkan data logger dan GSM modem tidak boleh basah atau lembab karena air.

d. Ujicoba dan pengamatan di pusat data, dilakukan dengan mengoperasikan software SMS gateway untuk mengendalikan data logger dan perangkat lunak database online monitoring.

e. Pelatihan pengoperasian sistem kepada operator data center.

\subsection{Lokasi Pemasangan}

Lokasi pemasangan sistem pemantauan kualitas air online ini adalah di intake PDAM Pontianak di tepi Sungai Kapuas. Berikut ini adalah informasi detail lokasi tersebut :

- Nama Stasiun: Intake PDAM Pontianak

- ID Stasiun : PDAM

- Alamat Stasiun: Jalan Imam Bonjol, Kota Pontianak

- Koordinat Lokasi : $00^{\circ} 02,478^{\prime}$ LS ; $109^{\circ}$ 21,203 ' BT 


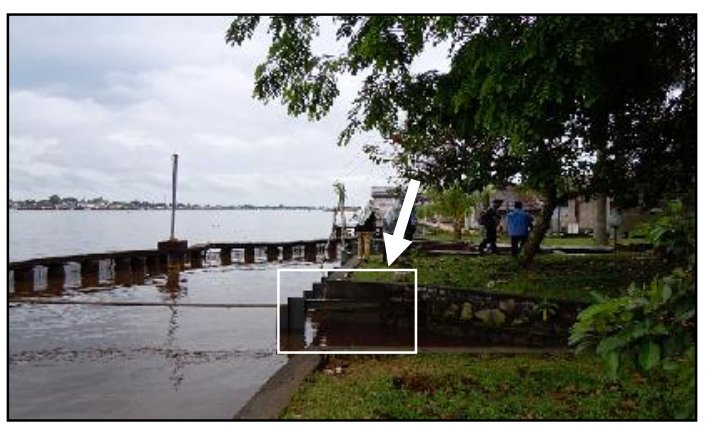

Gambar 4. Lokasi Intake PDAM Pontianak

\section{PEMBAHASAN}

\subsection{Penentuan Lokasi}

Lokasi pemasangan sistem sensor dipilih dengan memperhatikan kekuatan sinyal operator GSM, kemudahan teknis saat pemasangan dan masalah keamanan peralatan. Selain itu juga dengan memperhatikan pengaruh pasang-surut air Sungai Kapuas saat air pasang di musim hujan yang dapat mencapai ketinggian 1 meter dari permukaan tanah. Pilihan lokasi masih berada di dalam area / halaman PDAM Pontianak dan di pinggir / tepian Sungai Kapuas. Gambar di bawah ini adalah lokasi pemasangan sensor kualitas air.

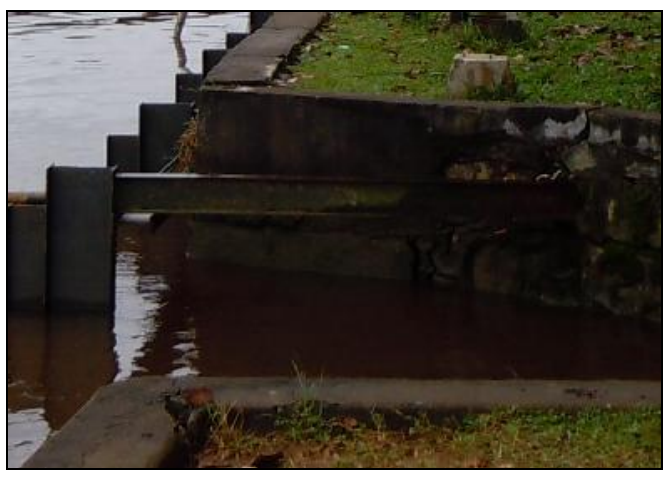

Gambar 5. Lokasi Pemasangan Sensor Kualitas Air

Lokasi penempatan data logger dipilih di dalam rumah pompa air baku dengan alasan keamanan dan sangat dekat dengan lokasi penempatan sensor, sehingga tidak diperlukan kabel data yang panjang, mengingat kabel data serial yang disediakan untuk sensor hanya memiliki panjang sekitar 8 meter. Selain itu kekuatan sinyal operator GSM dari dalam ruang pompa juga perlu diperhatikan. Gambar berikut ini adalah bagian belakang dan ruangan dalam bangunan pelindung rumah pompa air baku.
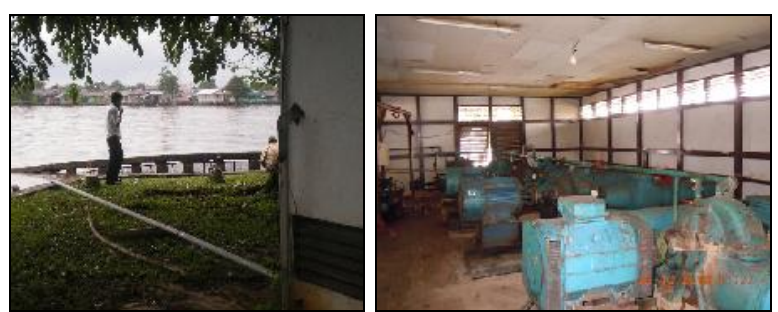

Gambar 6. Lokasi Penempatan Data Logger

Selain sensor dan data logger, pusat data juga perlu ditentukan untuk mempermudah operator dalam pengoperasiannya sehari-hari. Lokasi pusat data diletakkan pada ruangan dengan berpendingin $A C$ dan memiliki kekuatan sinyal operator GSM yang cukup baik dari dalam ruangan tersebut. Gambar berikut adalah foto lokasi penempatan komputer server di ruang pusat data di gedung utama PDAM Pontianak.

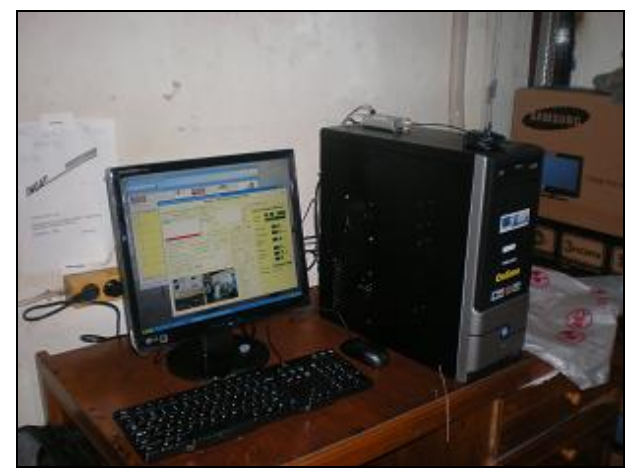

Gambar 6. Lokasi Pemasangan Komputer Server

\subsection{Pemilihan Operator Jaringan GSM}

Untuk memilih operator jaringan GSM sebelumnya dilakukan pengujian terhadap kekuatan sinyal GSM di lokasi penempatan sensor, lokasi penempatan data logger dan lokasi pusat data. Pengujiannya dilakukan secara manual, yaitu dengan menggunakan perangkat telepon genggam yang memiliki lebih dari satu Sim Card. Perangkat telepon genggam ini biasanya berasal dari merk-merk dagang buatan negeri bambu China.

Pengujian kekuatan sinyal GSM meliputi sim card : Simpati, AS, Halo, 3, XL, dan IM3, yaitu dengan membandingkan tinggi balok yang menandakan kekuatan sinyal dalam perangkat telepon genggam. Makin tinggi balok sinyalnya makin kuat dan baik sinyal tersebut pada posisi lokasi yang diuji. Untuk konfirmasi dilakukan survey juga ke beberapa operator/pegawai PDAM dengan menanyakan secara langsung operator GSM yang digunakan oleh mereka. Hasil survey pemilihan operator GSM ditetapkan untuk menggunakan Sim Card Kartu AS dari operator GSM Telkomsel. 
Ada dua pilihan model berlangganan kartu AS, yakni pra bayar dan pasca bayar. Disarankan untuk menggunakan kartu pasca bayar, yaitu dengan membayar abodemen dan membayar tagihan penggunaannya setiap akhir bulan untuk menjamin ketersediaan pulsa yang diperlukan selama pengoperasian alat. Jika dipilih kartu pra bayar, operator harus lebih sering memperhatikan sisa nilai nominal pulsa agar sistem komunikasi data tetap dapat beroperasi.

\subsection{Persiapan Peralatan}

Persiapan peralatan dilakukan dengan mengadakan unit multiprobe sensor, unit batere dan solar cell, personal komputer, 2 unit GSM modem, data logger dan aksesori perpipaan.

\subsubsection{Multiprobe Digital Sensor}

Multiprobe digital sensor adalah sensor kualitas air yang memiliki lebih dari satu probe yang dapat mengukur lebih dari satu parameter sekaligus secara bersamaan dengan output digital. Ada 6 jenis parameter kualitas air yang dapat diukur, yakni : (1). Suhu [oC], (2). Conductivity $[\mathrm{mS} / \mathrm{cm}],(3)$. TDS [g/l], (4). Salinity [ppt], (5). DO [mg/l], (6). pH. Selanjutnya untuk keperluan perawatan dan kalibrasi sensor, disediakan juga beberapa larutan standar $\mathrm{pH} 4,7$ dan 10 yang digunakan untuk melakukan kalibrasi parameter $\mathrm{pH}$, serta larutan $\mathrm{KCL}$ yang digunakan untuk pemeliharaan sensor DO (7).
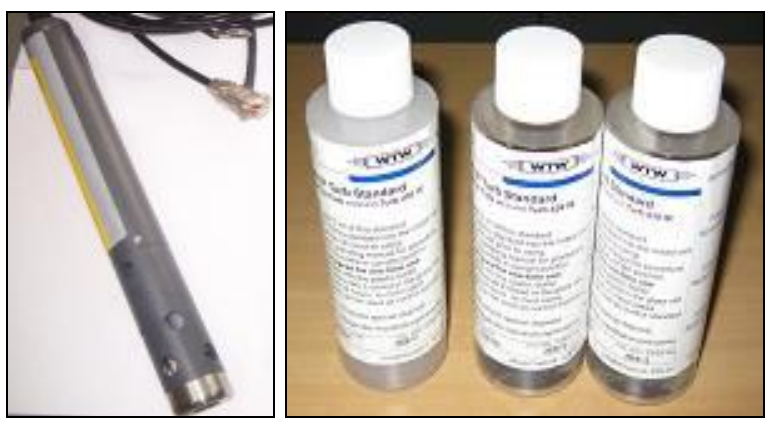

Gambar 7. Larutan Standar Untuk Kalibrasi

\subsubsection{Solar Cell dan Batere Kering}

Sebagai sumber energi listrik diberikan dua pilihan, yaitu energi listrik PLN dan solar cell yang dalam pengoperasiannya operator dapat memilihnya dengan memutar power switch ke salah satu arah. Energi listrik PLN akan diubah ke dalam power DC menggunakan 12 volt DC adaptor yang telah disediakan. Energi listrik yang berasal dari solar cell akan menyimpan tenaga listriknya ke dalam batere kering (12volt 7Ah) melalui regulator (12VDC 4 6A) yang dapat mengendalikan status pengisian batere tersebut. Pengisian hanya akan dilakukan bila tegangan pada aki kering kurang dari 11.4 volt dan akan berhenti otomatis bila tegangan telah mencapai 13.9 volt $(7)$
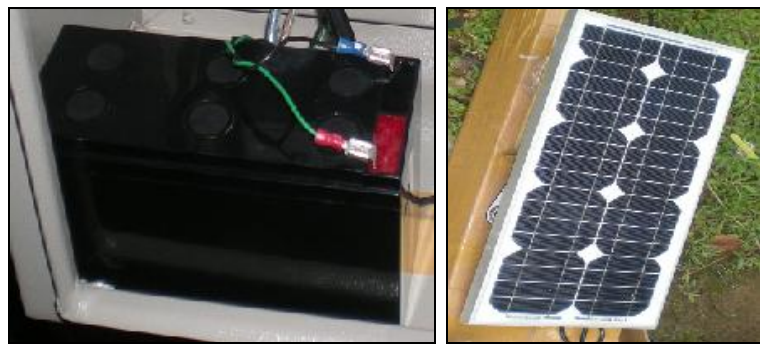

Gambar 8. Batere Kering dan Solar Cell

\subsubsection{Personal Komputer dan GSM Modem}

Untuk mengkomunikasikan sensor yang berada di dalam air melalui data logger, diperlukan perangkat keras komputer dan perangkat lunak di dalamnya. Personal komputer ini dipilih dengan spesifikasi teknis server karena akan dioperasikan layaknya sebuah server yang beroperasi 24 jam tanpa henti, sehingga diperlukan sistem pendingin dan UPS yang lebih baik. Spesifikasi minimal CPU adalah Pentium II, namun lebih baik jika menggunakan Pentium IV atau di atasnya (Core2Duo, Dual Core, atau iCore). Sebagai media transmisinya digunakan 2 unit GSM modem. Satu dipasang pada data logger dan satu dipasang pada komputer.

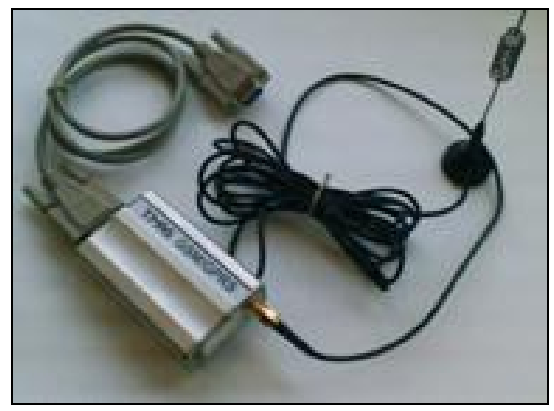

Gambar 9. GSM Modem

\subsubsection{Data Logger}

Data logger yang dikembangkan memiliki beberapa fitur utama, yaitu memiliki sistem pengiriman data berbasis SMS dan dapat lebih dari 164 karakter, interval waktu pengiriman dapat disetting dan dimonitoring dari pusat data, delay waktu pengukuran kualitas untuk early warning system hanya 60 detik, status memori dan status pengiriman data dapat dimonitoring dari pusat data, serta memiliki onsite display untuk menampilkan hasil pengukuran setiap saat di lapangan. Adapun spesifikasi teknis sistem data logger yang dikembangkan adalah ${ }^{(7)}$ : 
- $\quad$ Serial RS-232 port : 1 main, 3 slave

- 8 channel analog port

- 8 bit optocoupler TTL input, extendable to 40 bit

- 4 bit Transistor output, extendable to 20 bit

- 256 kByte flash memory

- Real Time Clock dan

- Dilengkapi PLC untuk EWS

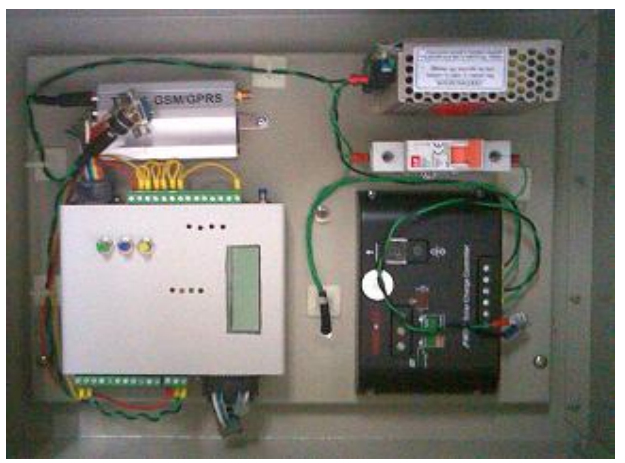

Gambar 10. Sistem Data Logger

\subsubsection{Aksesori Perpipaan}

Persiapan aksesori perpipaan harus disesuai dengan kondisi pemasangan sensor di lokasi. Sistem perpipaan dipersiapkan untuk melindungi perangkat sensor dari kotoran atau sampah yang ada di sungai dan melindungi kabel data yang terbentang dari sensor menuju data logger. Aksesori perpipaan dapat menggunakan bahan PVC atau pipa galvanis. Pada lokasi intake PDAM digunakan bahan PVC sebagai pelindung sensor, dan untuk melindungi kabel data digunakan pipa galvanis. Ukuran pipa yang digunakan adalah 2" dan 3" (8).

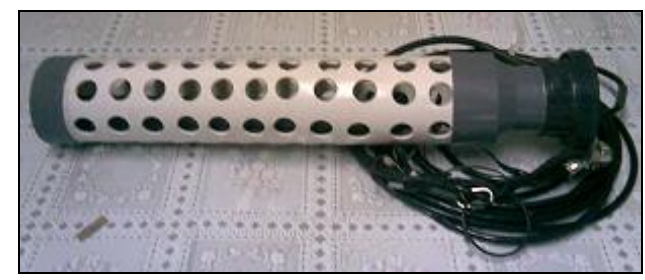

Gambar 11. Pipa PVC 3" Pelindung Sensor (8)

\subsubsection{Sistem Perangkat Lunak}

Sistem perangkat lunak yang dipersiapkan adalah SMS Gateway dan Database Online Monitoring. Kedua software ini dirancang dan dikembangkan agar dapat beroperasi secara bersama-sama dengan integrasi seluruh peralatan online monitoring yang akan dipasang. Software SMS Gateway digunakan sebagai pengendali pengiriman data melalui SMS dan software database digunakan sebagai sistem penyimpan dan penelusuran kembali data monitoring kualitas air (8).
Spesifikasi teknis perangkat lunak SMS gateway yang dikembangkan adalah ${ }^{(8)}$ :

- Multi station monitoring.

- Remote control memakai SMS \& perintah AT.

- Peringatan dini atau Early Warning System.

- Nilai baku mutu kualitas air dapat diset.

- Multi user SMS dan EWS.

- Interval waktu pengukuran dapat diset.

- Interval waktu pengiriman data dapat diset.

- Data record dalam format txt (pipe delimited).

- Terdapat informasi status batere, memori dan sisa pulsa untuk kartu prabayar.

- Terdapat fungsi peringatan dini di komputer (red blink).

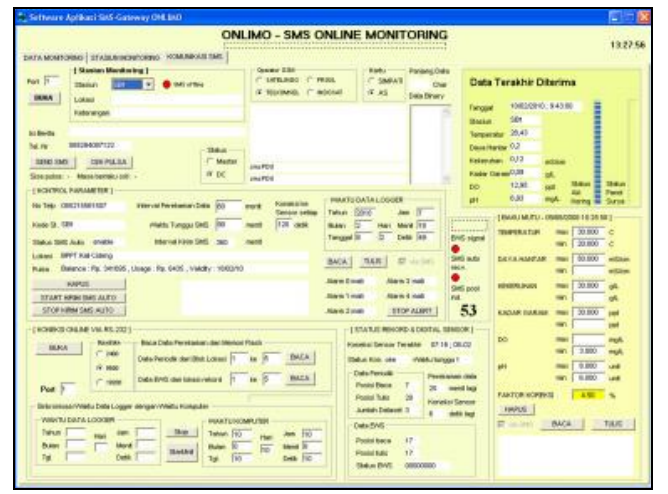

Gambar 12. Software SMS Gateway (8)

Spesifikasi teknis perangkat lunak database online monitoring kualitas air yang dikembangkan adalah (8) :

- Mengelola data stasiun dan data kualitas air.

- Penggunaan bersama file oleh aplikasi SMS Gateway melalui file data dalam format teks.

- Memantau data secara online dan realtime.

- Menampilkan data pengukuran dalam bentuk angka dan grafik analisa.

- Tersedia laporan ringkas, detail dan lengkap.

- Tersedia dokumen elektronik untuk online manual, regulasi dan data baku mutu.

- Penelusuran data : harian / bulanan / stasiun

- Dibuat dalam bahasa Indonesia.

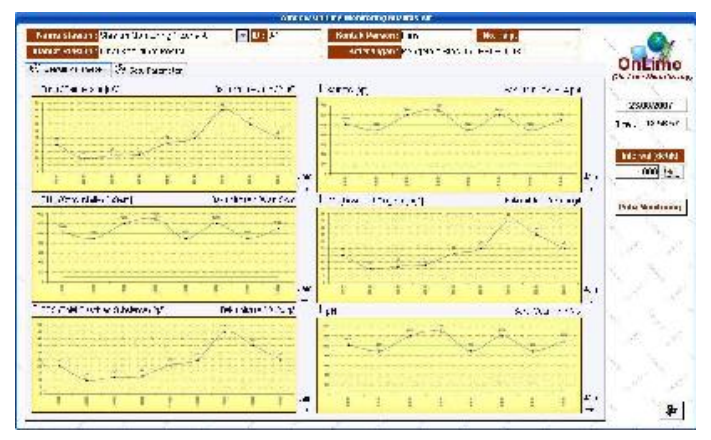

Gambar 13. Software Database Kualitas Air (8) 


\subsection{Instalasi/Pemasangan Peralatan}

Jika seluruh persiapan telah dilaksanakan, maka instalasi atau pemasangan seluruh komponen peralatan tidak membutuhkan waktu yang lama. Beberapa peralatan pertukangan akan diperlukan selama proses instalasi. Prosedur instalasinya mengikuti gambar rencana seperti di bawah ini :

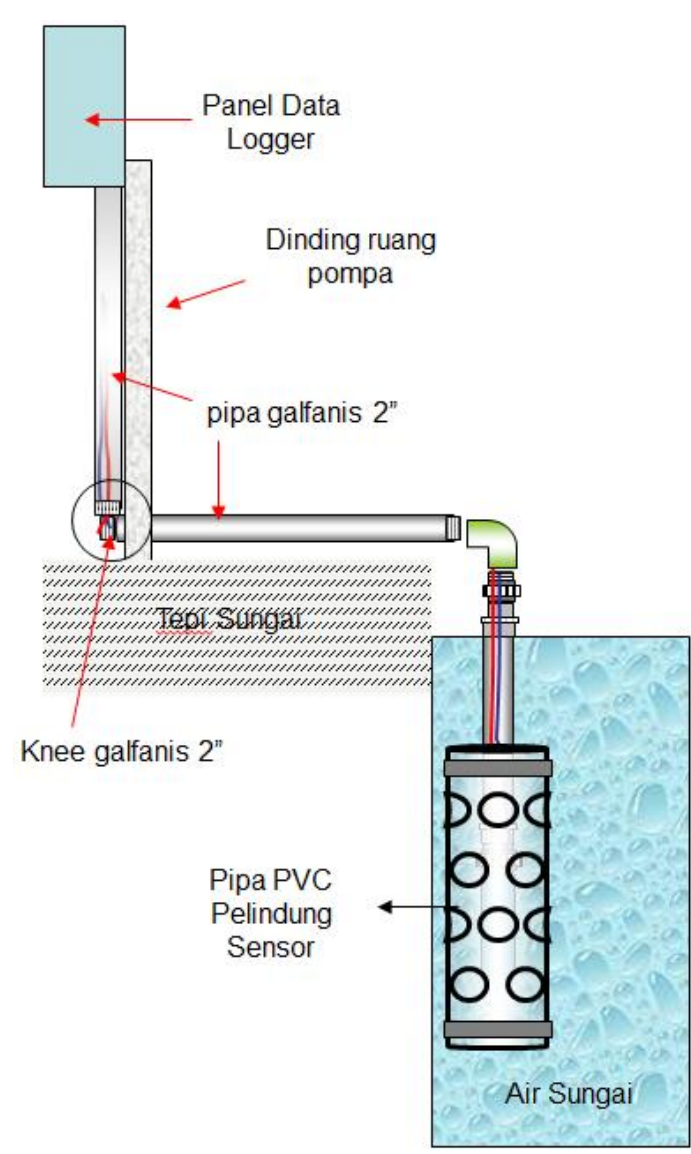

Gambar 14. Rencana Pemasangan Komponen Data Logger dan Sensor (6)

Langkah pertama adalah memasukkan sensor ke dalam casing pipa PVC 3" yang sudah disiapkan dengan water mur untuk memudahkan saat bongkarpasang. Selanjutnya pipa casing disambungkan dengan pipa PVC 2" kurang lebih 2 meter yang berfungsi untuk menempatkan sensor pada kedalaman 1,5 2 meter dari permukaan air sungai. Pada bagian atas pipa PVC 2" dipasang knee 2" yang disambungkan dengan sokdrat dalam 2" untuk pemasangan pipa galvanis 2". Kabel data dimasukkan ke dalam pipa PVC dan galvanis 2" ini menuju lokasi data logger di dalam ruang pompa. Diperlukan kurang lebih 7 meter pipa galvanis 2" untuk melindungi kabel data dari tepi sungai menuju dinding ruang pompa yang dimasukkan dari bawah dengan membuat lubang 2,5" untuk memasukkan knee pipa galvanis 2 ".
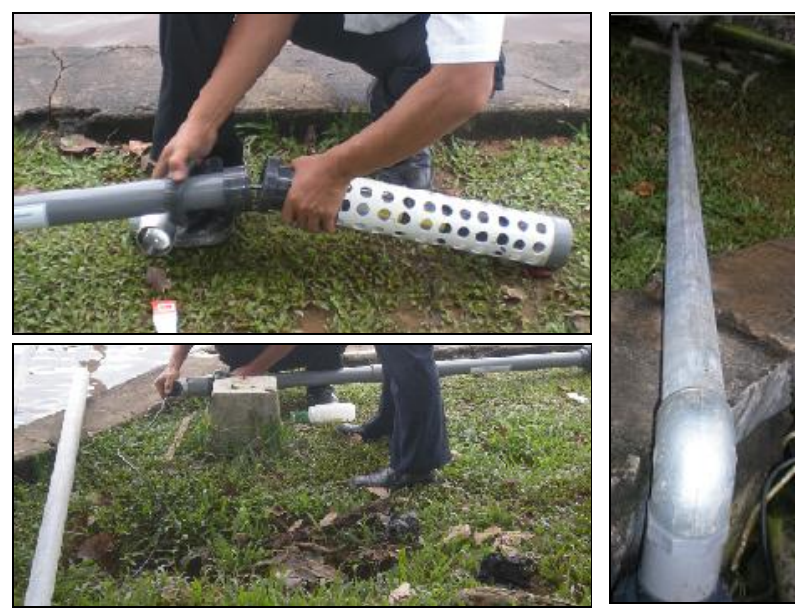

Gambar 15. Pemasangan Sistem Perpipaan Untuk Melindungi Sensor dan Kabel Data

Setelah sistem perpipaan disambung, lalu pipa sensor dicelupkan ke dalam sungai di tepi dinding. Untuk memperkuat pipa agar tidak mudah bergerak dapat digunakan klem pipa 2" yang dipaku ke dinding beton. Untuk melindungi keamanan sensor juga dapat dibuatan sangkar/krangkeng dari bahan besi yang dilas di atas besi $\mathrm{H}$ beam dan ditanam di dinding beton.
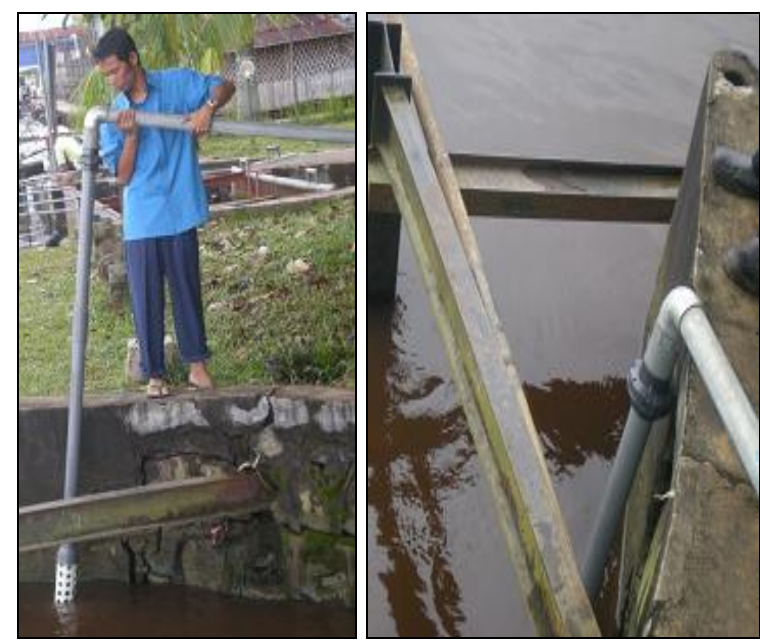

Gambar 16. Pipa PVC Berisi Sensor Yang Dimasukkan ke Air Sungai

Setelah memasang pipa sensor dan pelindung kabel data, langkah berikutnya adalah memasang panel data logger ke dinding rumah pompa pada ketinggian sekitar 1,5 meter dari permukaan tanah. Lokasi penempatan panel data logger tepat di atas lubang pipa galvanis yang menembus rumah pompa, sehingga kabel data dapat dengan mudah dimasukkan ke dalam kota panel data logger. Pada lokasi ini juga disediakan sumber listrik PLN sebagai sumber listrik alternatif setelah solar cell. 

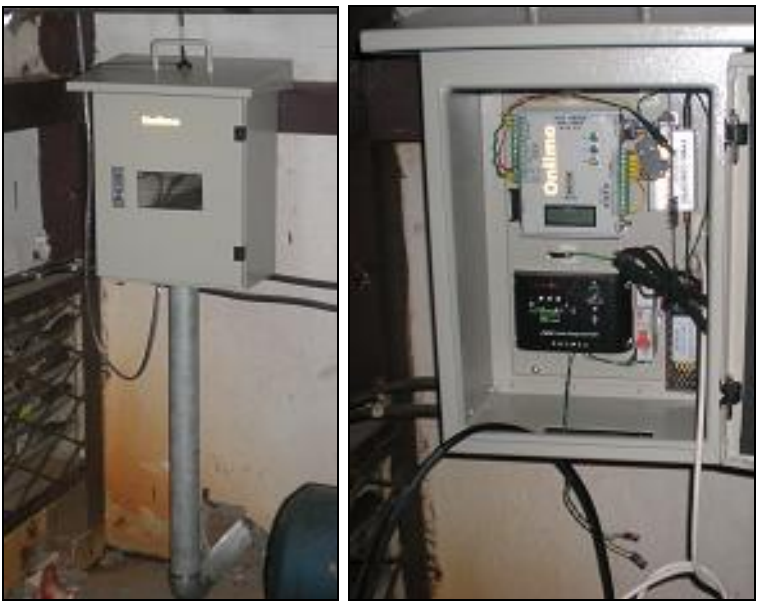

Gambar 17. Pemasangan Data Logger pada Dinding Rumah Pompa

Sumber energi listrik data logger yang utama adalah solar cell. Penempatan solar cell dipilih lokasi yang memiliki pencahayaan sinar matahari paling terang dan tidak terhalang oleh ranting dan daun pohon di sekitarnya. Jika data logger terpasang pada dinding bagian belakang rumah pompa, maka dari hasil survei ditentukan lokasi pemasangan solar cell adalah di sisi sebelah kiri bagian depan rumah pompa, karena lokasi ini yang memiliki pencahayaan yang memenuhi syarat. Untuk itu perlu menyiapkan kabel listrik untuk memasang solar cell menuju data logger yang berjarak kurang lebih 10 meter.

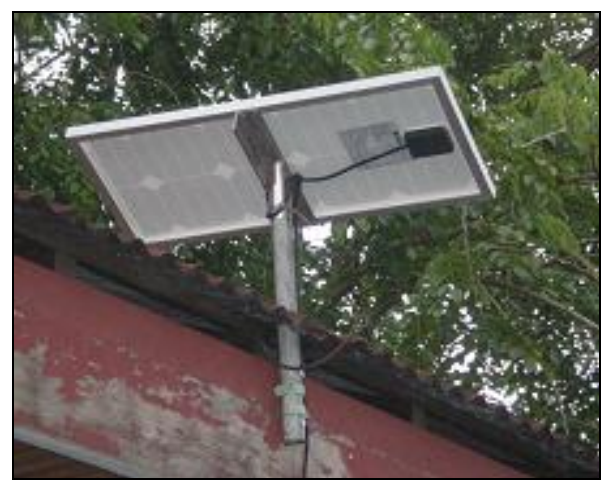

Gambar 18. Solar Cell Yang Sudah Terpasang

Solar cell dipasang sedemikian rupa sehingga menghadap cahaya matahari ke atas dengan menggunakan pipa $11 / 4$ " yang dipaku dengan klem pipa $1 \frac{1}{4}$ " ke lisplang atap rumah pompa. Untuk menghindari terhalangnya sinar matahari yang mengenai permukaan solar cell, telah disarankan untuk menebang sebagian ranting dan dahan yang berada di lokasi solar cell.

Setelah semua peralatan outdoor selesai dipasang, selanjutnya adalah mengaktifkan komputer di ruang pusat data. GSM modem dipasang melalui konektor serial RS232C pada bagian belakang komputer. Pada personal komputer biasanya konektor serial RS232C ini dialokasikan pada nomor port 1 atau COM1. Nomor port ini yang selanjutnya akan digunakan pada saat konfigurasi dan setting sistem software SMS Gateway ${ }^{(8)}$.

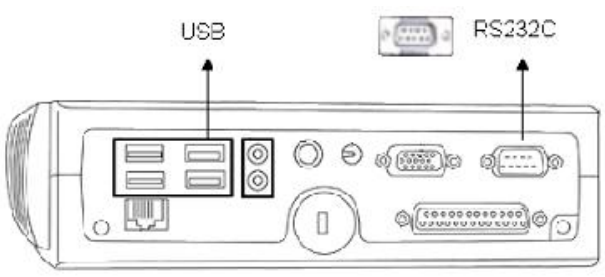

Gambar 19. Konektor Serial RS232C

\subsection{Ujicoba Operasional}

\subsubsection{Setting Konfigurasi Pengukuran}

Setting konfigurasi pengukuran yang standar ditentukan dengan beberapa parameter konfigurasi, yaitu : interval waktu pengukuran adalah 1 jam sekali dan interval peringatan dini 60 detik. Sehingga dalam sehari akan diperoleh 24 data pengukuran kualitas air. Sedangkan interval waktu keterlambatan peringatan dini adalah 60 detik. Selain setting konfigurasi interval waktu pengukuran, dilakukan pula setting interval pengiriman data pengukuran yang dilakukan setiap 6 jam guna menghemat biaya SMS. Jadi dalam sehari ada 4 kali biaya transaksi pengiriman SMS berisi data pengukuran. Namun setiap saat Program Logic Control (PLC) di dalam data logger dapat mengirimkan data pengukurannya apabila hasil pengukurannya tidak memenuhi baku mutu yang telah ditentukan. Adapun nilai baku mutu yang ditentukan dalam data logger adalah (8):

- Temperatur : $20^{\circ} \mathrm{C} \sim 30^{\circ} \mathrm{C}$

- Konduktifitas maksimal : $50 \mathrm{mS} / \mathrm{cm}$

- TDS maksimal : $30 \mathrm{~g} / \mathrm{l}$

- Salinitas maksimal : $30 \mathrm{ppt}$

- DO minimal : $3 \mathrm{mg} / \mathrm{l}$

- $\mathrm{pH}: 6 \sim 8$

\subsubsection{Pengoperasian Sistem}

Pengoperasian sistem diawali dengan mengaktifkan data logger. Indikator bahwa data logger bekerja dengan baik adalah berkedipnya lampu led merah dan kuning pada data logger bergantian dengan interval waktu yang sama dan berulang. Kemudian pada software SMS gateway di pusat data, didaftarkan beberapa nomor HP operator dan pejabat terkait di lingkungan PDAM Pontianak. Ada dua kategori pengguna, yaitu pengguna informasi periodik dan informasi EWS, seperti contoh berikut : 
- File : C:IOnlimolDataUserOnlimo.TXT

\begin{tabular}{l|}
\hline 08121936XXX,HDW, Developer \\
0811576XXX,Henny, Untan \\
081510341XXX,Lord, NSN \\
08111750XXX,Irvandi,NSN \\
05617041XXX,Supiandi, Data center \\
05617956XXX,Wawan,PDAM \\
085693087XXX,Tano Baya,PDAM \\
\hline
\end{tabular}

- File : C:IOnlimolDataUserEWS.TXT

$$
\begin{aligned}
& \text { 08121936XXX,HDW, Developer } \\
& \text { 0811576XXX,Henny, Untan } \\
& \text { 05617041XXX,Supiandi, Data center } \\
& \text { 085693087XXX,Tano Baya,PDAM }
\end{aligned}
$$

Untuk menguji jalur komunikasi antara data logger dan pusat data, dilakukan prosedur cek status ke nomor data logger (085215844XXX). Dibutuhkan waktu 1 menit untuk mendapatkan informasi status data logger. Jika proses komunikasi melalui SMS berhasil, maka pada SMS Gateway akan muncul informasi data status operasi data logger seperti pada gambar berikut.

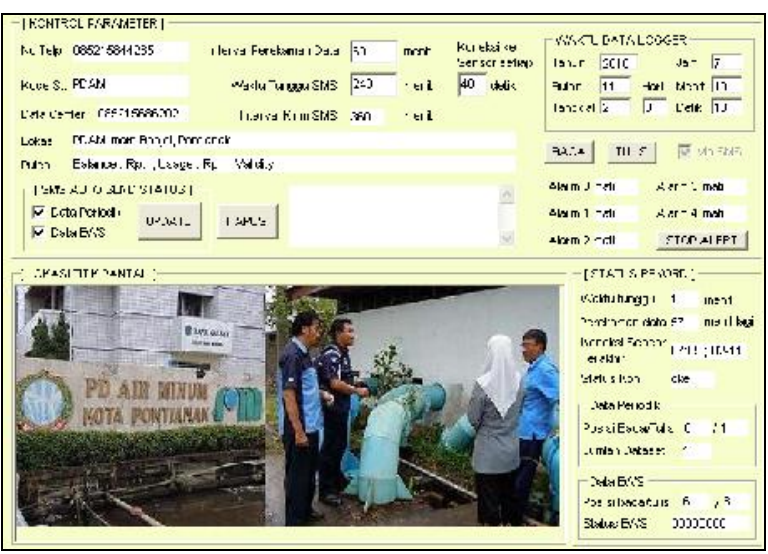

Gambar 20. Status Operasi Data Logger

Yang perlu diperhatikan pada tampilan informasi di atas adalah :

- Pada SMS AUTO SEND STATUS, jika kolom cek Data Periodik dan Data EWS tercentang berarti setting konfigurasi aktif. Klik kolom ceknya jika ingin diaktifkan atau dimatikan.

- Interval Perekaman Data : 60 menit berarti interval waktu pengukurannya 1 jam sekali.

- Waktu Tunggu SMS : 240 menit berarti waktu pengiriman data berikutnya adalah 4 jam kemudian.

- Interval Kirim SMS : 360 menit berarti interval pengiriman data pengukuran setiap 6 jam sekali.

- Koneksi Sensor Setiap : 40 detik berarti delay waktu peringatan dini adalah 40 detik.
Selain informasi di atas, masih banyak lagi data informasi yang diperoleh mengenai status data logger, diantaranya adalah WAKTU DATA LOGGER yang harus sinkron dengan waktu pada komputer pusat data, STATUS RECORD yang menunjukkan posisi perekaman data pada memori data logger, dan Alarm sistem yang berjumlah 5 buah. Alarm sistem ini dapat diaktifkan untuk memberikan informasi kepada operator apabila ada komponen sistem monitoring yang terhubung atau hilang. Sistem akan mengirimkan SMS dan menyalakan alarm (red blink) pada program SMS Gateway. Status batere atau aki kering, nilai tegangannya dan angka baku mutu parameter juga dapat diketahui statusnya melalui SMS Gateway.

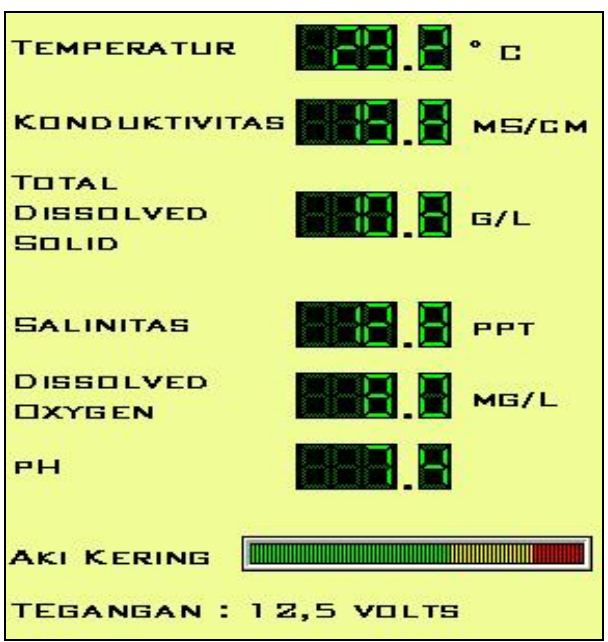

Gambar 21. Status Betere/Aki, Tegangan dan Nilai Baku Mutu Parameter Pada Data Logger

Pengujian komunikasi juga dilakukan dengan mengirimkan SMS permintaan informasi data oleh pengguna yang telah terdaftar sebagai pengguna informasi periodik. Nomor telepon user ini harus terdaftar pada database user informasi periodik (File : DataUserOnlimo.TXT). Format penulisan SMS permintaan informasi data periodeik adalah : "Onlimo 2010". Jadi berita SMS yang berisi dua suku kata di atas dikirimkan ke nomor telepon GSM modem pada pusat data. Setelah beberapa saat, maka SMS Gateway pada pusat data akan mengirimkan informasi data pengukuran terakhir yang sudah diterima oleh SMS Gateway seperti contoh di bawah :

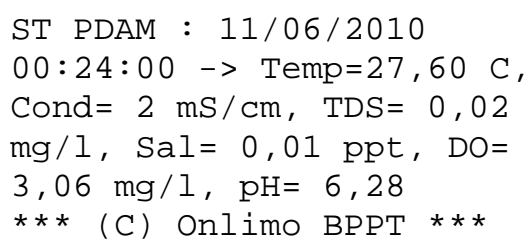




\subsubsection{Hasil Pengukuran Kualitas Air}

Pengujian operasional sistem monitoring yang dilakukan selama beberapa jam telah mendapatkan beberapa record data pengukuran yang disimpan secara otomatis oleh SMS Gateway dalam format text ke file : C:IOnlimol DataPengukuran.TXT. Gambar berikut ini adalah contoh isi file tersebut jika dibuka menggunakan aplikasi notepad.

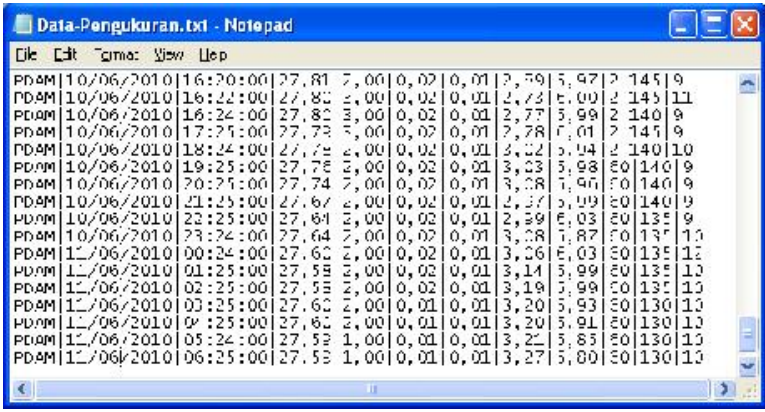

Gambar 22. Data Hasil Pengukuran Yang Sudah Tersimpan Dalam File di Komputer Pusat Data

Tampilan grafik hasil pengukuran tersebut dapat dilihat seperti gambar di bawah ini.

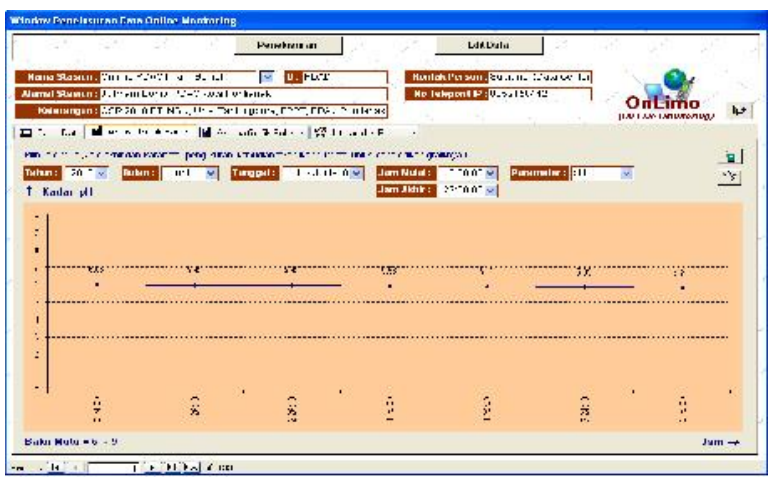

Gambar 23. Grafik Hasil Pengukuran Saat Ujicoba Operasional Sistem

\subsection{Pelatihan Operator}

Pelatihan diberikan kepada operator yang berasal dari bagian pengelolaan data, bagian laboratorium dan bagian produksi di lingkungan PDAM. Pelatihan yang diberikan kepada operator meliputi beberapa kegiatan, diantaranya adalah :

- Bongkar pasang sistem data logger dan perpipaannya.

- Mengaktifkan dan mematikan sistem.

- Memantau status data logger, sensor dan solar cell melalui komputer pusat data.

- Mengubah setting konfigurasi interval waktu pengukuran.

- Pengoperasian software SMS Gateway.
- Pengelolaan data menggunakan software database online monitoring kualitas air.

- Trouble shooting untuk permasalahan sederhana yang mungkin muncul sehari-hari.

- Kalibrasi sensor menggunakan notebook di lapangan.

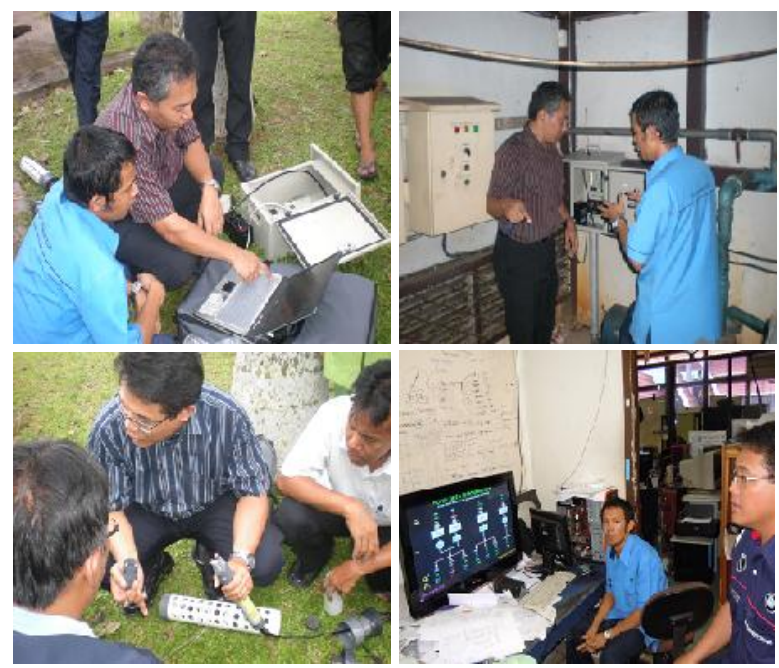

Gambar 24. Pelatihan Operator

\section{KESIMPULAN}

Dari hasil kegiatan instalasi sistem pemantauan kualitas air online berbasis GSM di Sungai Kapuas dapat diambil beberapa kesimpulan sebagai berikut :

- Pemilihan titik lokasi pemasangan sensor telah berpindah dari lokasi awal yang direncanakan di dalam bak air baku yang hanya berjarak 4 meter dari pinggir sungai ke dalam lokasi pintu intake yang berada di pinggir sungai dengan alasan untuk mendapatkan data perubahan TDS yang lebih akurat. Pemindahan lokasi berpengaruh kepada sistem perpipaan dan pengamanan peralatan sensor.
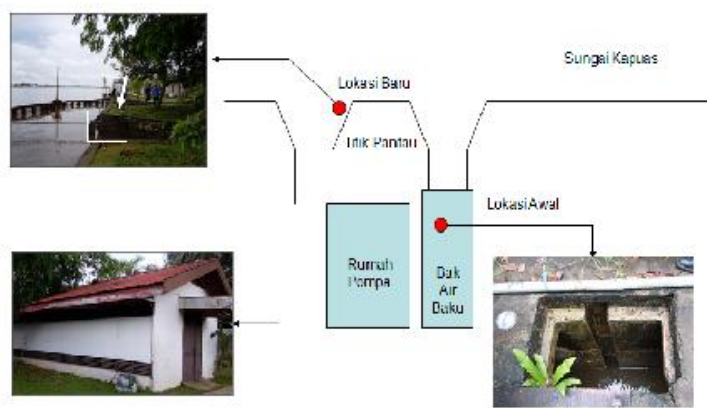

Gambar 25. Perpindahaan Lokasi Sensor

- Penggunaan pipa galvanis berukuran 2" untuk melindungi kabel data mempersulit kegiatan pemeliharaan sensor karena lebih sulit untuk dibongkarpasang dan lebih berat 
jika dibandingkan dengan pipa PVC dengan ukuran yang sama 2". Namun pipa galvanis lebih rigid dan tidak melengkung jika diletakkan di permukaan tanah dan tidak perlu dilindungi dengan adukan semen.

- Lokasi rumah pompa yang terlalu rindang karena banyak pepohonan membuat sulitnya memperoleh titik penempatan solar cell yang dapat langsung terkena cahaya matahari. Jika terlalu jauh dari data logger akan membutuhkan kabel yang lebih panjang dan tidak efektif dalam penyimpanan energi surya menjadi energi listrik dalam aki kering.

- Lokasi rumah pompa yang sudah terdapat sumber listrik PLN, dapat menjadi sumber listrik alternatif bagi data logger saat cuaca mendung dan turun hujan atau saat solar cell tidak dapat mengisi aki kering. Kota Pontianak memiliki curah hujan yang cukup tinggi, yaitu 3000 4000 mm per tahun (1).

- Dalam pengoperasiannya divisi teknis ingin melalukan pemantauan dengan interval 10 menit sekali yang disesuaikan dengan sistem peralatan monitoring lainnya. Namun untuk sistem monitoring kualitas air yang dipasang interval tersebut tidak memberikan perbedaan data pengukuran yang signifikan, sehingga disarankan untuk tetap melakukan pengukuran dengan interval 1 jam sekali, karena dengan interval tersebut dapat lebih menghemat biaya pengiriman SMS.

\section{DAFTAR PUSTAKA}

1. Wikipedia, Ensiklopedia Bebas, http://id.wiki pedia.org/wiki/Kota_Pontianak, 2011

2. Pemkot Pontianak, Jumlah Penduduk, Dinas Kependudukan \& Catatan Sipil Kota Ponitanak, 2008.

3. Pemkot Pontianak, Situs Resemi Pemerintah Kota Pontianak, http://www.pontianakkota.go .id/, 2011

4. Dirjen Cipta Karya, Situs Resmi Direktorat Jenderal Cipta, http://ciptakarya.pu.go.id/, 2011.

5. Primair Online, Air PDAM Pontianak Tidak Layak Dikonsumsi, http://www.primaironline. com/berita/nusantara/air-pdam-pontianaktidak-layak-dikonsumsi, 2009)

6. Henny dan Heru, Sistem Monitoring Kualitas Air Online, Seminar Pemantauan Kualitas Air Sungai Kapuas, Pontianak 2010)

7. Heru Dwi Wahjono dan Bayu Budiman, Sistem Manajemen Komunikasi Data Jarak Jauh Berbasis Teknologi SMS dan Radio Telemetri Untuk Pemantauan Kualtias Air, JTL Vol 7 No. 2 Mei 2006

8. Bayu Budiman dan Heru Dwi Wahjono, Petunjuk Operasional Sistem Onlimo Sungai Kapuas, Pusat Teknonologi Lingkungan BPPT, 2010

\section{LAMPIRAN}

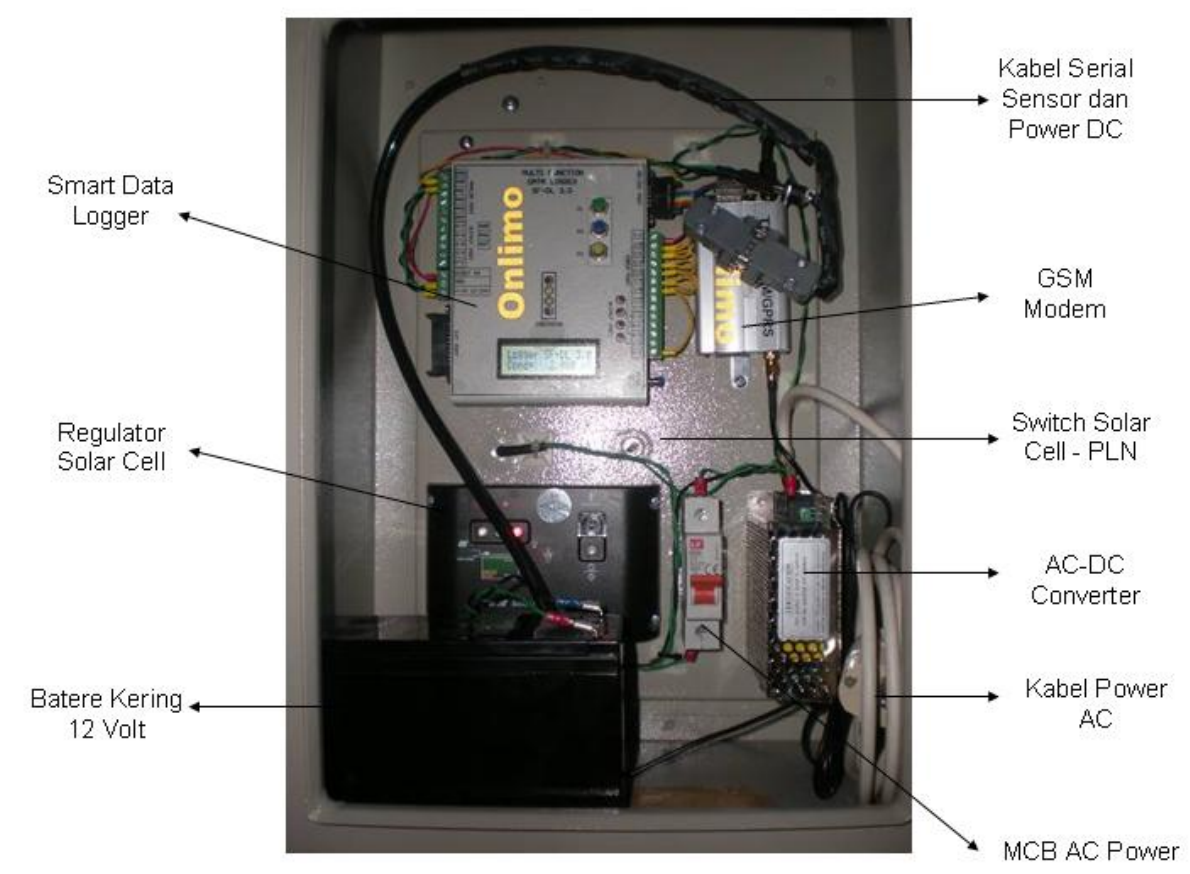

Gambar 26. Komponen Data Logger yang Terpasang 


\begin{abstract}
Abstrak
Sungai Kapuas merupakan sungai terbesar di Pulau Kalimantan yang menjadi sumber air bagi masyarakat pulau ini. Di Kota Pontianak Sungai Kapuas merupakan sumber air baku bagi PDAM kota ini. Untuk menjaga kualitas produknya, PDAM Kota Pontianak telah melakukan pemantuan kualitas air sungai ini secara rutin. Hal ini dilakukan karena pada saat musim kemarau atau saat air pasang, kualitas air baku sungai Kapuas ini menjadi asin. Sedangkan pada saat musim hujan lebat air sungai ini membawa lumpur dari hulu dan berubah menjadi air gambut. Untuk memantau terjadinya perubahan kualitas air sungai Kapuas di intake PDAM Kota Pontianak telah diinstalasikan sistem pemantuan kualitas air online dan realtime berbasis GSM. Tulisan ini membahas proses instalasi sistem pemantuan kualitas air online mulai dari persiapan, penentuan lokasi sampai dengan proses ujicoba sistem. Hasil pemantauan oleh sistem monitoring ini diharapkan dapat membantu bagian produksi untuk menentukan tindakan yang diperlukan jika terjadi perubahan kualitas terhadap air baku sungai Kapuas.
\end{abstract}

Kata Kunci : SIstem Pemantauan Online Berbasis Komunikasi GSM, Sistem Telemetri, Sumber Air Baku PDAM Pontianak, Multi Probe Digital Sensor, Instalasi Pengolahan Air

\begin{abstract}
Kapuas River is the largest river on the Borneo island and become the source of water for the people of this island. In Pontianak City, Kapuas River is become the source of raw water for the local water company (PDAM). To maintain product quality, PDAM Pontianak always monitor this river water quality. During the dry season or during high water, raw water quality Kapuas river becomes salty. Meanwhile, during the rainy season brings torrential river water from upstream mud and water turned into peat. To monitor water quality changes in the Kapuas river in the intake location, PDAM Pontianak has installed an online and real time water quality monitoring system using GSM technology. This paper discusses the installation process online water quality monitoring system starting from the preparation, determination of the location until the process of testing the system. The results of monitoring by the monitoring system is expected to assist the production department to determine the necessary action if there is a change of quality of raw water Kapuas river.
\end{abstract}

Keywords: GSM Communication Based Online Monitoring System, Telemetry System, Intake PDAM Pontianak, Multi Probe Digital Sensor, Water Treatment Plant 